\title{
Recent Developments in Automotive Exhaust Gas Sensing
}

\author{
R. Moos \\ Bayreuth Engine Research Center, University of Bayreuth, 95440 Bayreuth, Germany \\ Phone: +49 92155 7400, Fax: +49 921557405 , \\ E-mail: Functional.Materials@Uni-Bayreuth.de
}

\section{Novel exhaust gas aftertreatment systems}

Increasing fuel costs combined with the pressure on the automotive industry to reduce $\mathrm{CO}_{2}$ emissions lead to booming market shares for Diesel passenger cars. They are operated leanly. Therefore, nitrogen oxide $\left(\mathrm{NO}_{\mathrm{x}}\right)$ removal with conventional three way catalysts (TWC) is not possible, e.g. [1]. At the same time, $\mathrm{NO}_{x}$ emission limits have been strongly reduced. Leanly operated gasoline direct injection engines are another way for reducing fuel consumption. Both lean concepts require novel exhaust gas aftertreatment concepts, especially for $\mathrm{NO}_{\mathrm{x}}$ abatement.

The ammonia SCR process prevails for $\mathrm{NO}_{x}$ removal of coal power plant exhausts. This process has been adapted for automotive requirements. For heavy duty vehicles, systems are already in serial application, and recently, they have been serialized for passenger cars as well.

$\mathrm{NO}_{x}$ storage catalysts (often denoted as lean $\mathrm{NO}_{x}$ traps, LNT) were developed and have been introduced for gasoline direct injection engines. Here, during a lean phase, $\mathrm{NO}_{x}$ is adsorbed and stored in the form of nitrates. Nitrate reduction occurs in a short rich phase, just before the $\mathrm{NO}_{x}$ storage capacity of the LNT is exhausted and it begins to let pass $\mathrm{NO}_{x}$.

In the meantime, LNTs are also in serial production for the aftertreatment of Diesel engine exhausts, as well as the SCR system is in discussion for gasoline direct engines. Even the combination of both $\mathrm{NO}_{x}$ removal technologies, in which ammonia is formed during a short rich phase, is in serial application [2]. For both novel $\mathrm{NO}_{x}$ removal technologies, ammonia SCR and LNT, novel exhaust gas sensors that supplement the well-known and mature lambda-probe might be helpful.

Due to the strongly reduced particulate matter limits, Diesel particulate filters have been serialized. Besides a differential pressure sensor to detect the exhaust back pressure and to initiate filter regeneration, a soot sensor might be helpful to detect cracks in or damages of a Diesel particulate filter, which would result in a low backpressure but also in a low particulate reduction efficiency. However, soot sensors are not considered here.

\section{Exhaust gas sensors for lean $\mathrm{NO}_{\mathrm{x}}$ traps}

In the 1990ies, an exhaust gas $\mathrm{NO}_{\mathrm{x}}$ sensor device that bases on the zirconia technology of the planar lambda-probe has been proposed [3] (c.f. Ref. [4] for planar lambda-probe technology). This sensor can not only measure $\mathrm{NO}_{\mathrm{x}}$ but also the oxygen concentration in the lean exhaust. An additional binary lambda signal is also provided [5]. It shows only very small cross sensitivities to components that are usually present in the exhaust $\left(\mathrm{CO}_{2}, \mathrm{O}_{2}, \mathrm{CO}, \mathrm{HC}, \mathrm{H}_{2}, \mathrm{SO}_{2}\right)$. An ammonia cross sensitivity remains, which can be used for SCR purposes (see below) [6]. The sensor is in serial use for novel gasoline direct injection engines with lean $\mathrm{NO}_{x}$ traps as well as for heavy duty ammonia SCR systems. Due to the low occurring currents, the sensor is relatively complex and costly and it is in discussion whether the sensor is accurate enough to meet the requirements for future OBD [7]. 
Recent papers on $\mathrm{NO}_{\mathrm{x}}$ exhaust gas sensors review the research efforts for novel principles and materials [8], [9]. By carefully reading these reviews one gets the impression that no competing principle to the available $\mathrm{NO}_{x}$ sensor will reach serial ripeness in the near future.

It is a disadvantage of all NOx sensors that they measure a gas concentration but they do not gauge directly the NOx loading level of the LNT (which is the target parameter) and that no direct means are available to gauge the aging state of a lean $\mathrm{NO}_{\mathrm{x}}$ trap. A novel sensor for directly determining the state of a NOx storage catalyst was presented recently [10], [11]. It consists of interdigital electrodes deposited on a planar substrate. A resistance thermometer is applied on the reverse side. Both sides are covered with the original LNT coating, allowing detecting directly electrical impedance and temperature of the coating. Such sensors were integrated in different positions of an LNT. In synthetic exhausts as well as in dynamometer tests it is shown that in-situ measurements of the electrical impedance of the LNT coating are an appropriate means to determine directly the catalyst state. Hence, the local degree of NOx loading as well as the local regeneration status can be measured. Furthermore, sulfur poisoning, desulfurization, and thermal ageing can be directly seen [10], [11], [12].

\section{Exhaust gas sensors for ammonia SCR}

With ammonia SCR technology, $\mathrm{NO}_{x}$ can be selectively reduced in lean exhausts. AdBlue ${ }^{\mathrm{tm}}$, a urea-water solution, is injected into the exhaust where it decomposes to $\mathrm{NH}_{3}$ and $\mathrm{CO}_{2} . \mathrm{NO}_{\mathrm{x}}$ reacts with the formed $\mathrm{NH}_{3}$ in the SCR catalyst to $\mathrm{N}_{2}$ and $\mathrm{H}_{2} \mathrm{O}$. Since $\mathrm{NO}_{x}$ conversion depends on parameters like temperature, oxygen content, $\mathrm{NO}$ and $\mathrm{NO}_{2}$ concentration, space velocity, and also on the amount of previously stored $\mathrm{NH}_{3}$, and since in contrast to power plant applications transient operations prevail in automotive applications, a closed-loop controlled system would be beneficial, on the one hand to increase NOx conversion [13] and on the other hand to effectively and reliably monitor the catalyst state (on-board diagnosis, OBD).

The serial development is heading in two directions. Selective exhaust gas sensors like an $\mathrm{NO}_{\mathrm{x}}$ sensor or an $\mathrm{NH}_{3}$ sensor are already in serial use or are announced to enter the market soon. All these sensors base on the platform of planar lambda sensors and take advantage of the high degree of maturity of planar zirconia sensors and the long experience in manufacturing and operating these devices.

A highly developed $\mathrm{NH}_{3}$ sensor was presented recently by Delphi. The sensor uses the mixed potential principle, i.e., between two different electrodes, which are separated by the solid electrolyte YSZ, an electromotive force forms. Heater and insulating layers are identical with Delphi's planar lambda sensor.

In contrast to the lambda-probe, the inner reference electrode is in contact with the exhaust gas [14]. The sensor is based on a non-equilibrium electrochemical principle (mixed potential sensor). The measuring electrode contains SCR active materials [15], i.e. vanadium oxide, molybdenum oxide and/or tungsten oxide that are doped with materials like $\mathrm{Bi}$ and with stabilizers to improve the long-term stability. At the electrodes, oxidation and reduction reactions compete with each other [16]:

$1 / 2 \mathrm{O}_{2}+2 \mathrm{e}^{-}+\mathrm{V}_{\mathrm{O}} \cdot \rightarrow \mathrm{O}_{\mathrm{O}}$

$2 / 3 \mathrm{NH}_{3}+\mathrm{O}_{\mathrm{O}} \rightarrow \mathrm{H}_{2} \mathrm{O}+1 / 3 \mathrm{~N}_{2}+2 \mathrm{e}^{-}+\mathrm{V}_{\mathrm{O}} \cdot$

As a result, an ammonia dependent voltage difference $U$ between both electrodes occurs:

$U=\frac{k T}{2 e}\left(\frac{2}{3} \ln p_{\mathrm{NH}_{3}}-\frac{1}{2} \ln p_{\mathrm{O}_{2}}-\ln p_{\mathrm{H}_{2} \mathrm{O}}\right)$

According to Eq. 3, the sensor seems cross sensitive to oxygen and water. However, since both gases are correlated by the air-to-fuel ratio, i.e., an increasing air excess leads to a reduced water concentration in the exhaust, both cross sensitivities have an opposite effect and partly cancel out each other in a wide air-to-fuel range. The sensor was reported to perform well when tested in a Diesel engine exhaust environment and seems to have no cross interferences with $\mathrm{CO}, \mathrm{HC}, \mathrm{NO}$, and $\mathrm{N}_{2} \mathrm{O}$. A reversible $\mathrm{SO}_{2}$ poisoning effect was observed. $\mathrm{NO}_{2}$ had a strong influence but could have been corrected by an additional $\mathrm{NO}_{2}$ electrochemical cell, which is built into the existing $\mathrm{NH}_{3}$ sensor device. The $\mathrm{NO}_{2}$ sensing cell is also based on the non-equilibrium electrochemical principle. It shares a common reference electrode with the $\mathrm{NH}_{3}$ sensing cell [16]. Further details can be found in [17].

A less complicated mixed potential ammonia sensor was presented recently [18], [19]. It consists of a thick-film heater covered with insulating layers and a YSZ solid electrolyte. Both porous electrodes are in contact with the exhaust. In contrast to the above-described setup, it consists of two porous gold 
electrodes. As a novelty, one of the electrodes is covered with a porous catalytically active layer. It is the basic idea to separate the functions of a classical active electrode for mixed potential sensors, which are: 1.) to be electrically conductive, 2.) to ensure a high selectivity and 3.) to be long-term stable. Commercially available SCR catalyst materials were used, since they are known for their good selectivity combined with a proven long-term stability in real exhausts. Good results were obtained with titaniabased vanadia-tungsten oxide formulations. The NOx cross-sensitivity is marginal. If enough oxygen is in the exhaust, the sensor signal is independent on the oxygen concentration [20]. Tests downstream of an SCR catalyst show that very small ammonia slips can be determined [21]. Initial engine tests are very promising [20].

A combination of $\mathrm{NiO} / \mathrm{Au}$ sensing electrodes in combination with platinum reference electrodes were also found out to be selective [22]. In contrast to the above-described mixed potential sensors, this sensor behaves linear but with a much lower sensitivity. It is operated at $800^{\circ} \mathrm{C}$. The sensor signal is almost unaffected by $\mathrm{H}_{2} \mathrm{O}, \mathrm{NO}$, and $\mathrm{CO}$ and is only slightly affected by hydrocarbons. $\mathrm{NO}_{2}$ has an opposite but smaller effect. It seems that the sensor has to be operated under constant oxygen excess [22].

Control and monitoring of the SCR system via the ammonia cross sensitivity of the zirconia-based NOx sensor (see above) is also possible [23]. The cross sensitivity to ammonia can be easily understood. It is an additional effect. At the high sensor temperatures, a part of the ammonia gets oxidized according to $2 \mathrm{NH}_{3}+5 / 2 \mathrm{O}_{2} \rightarrow 2 \mathrm{NO}+3 \mathrm{H}_{2} \mathrm{O}$.

The resulting NO leads to the additional contribution to the sensor signal. For practical use, a cross sensitivity factor has to be introduced [24]. It is a major advantage of this sensor that it is already commercially available for NOx sensing purposes in the exhaust.

The idea of a direct SCR catalyst loading gauge was also investigated [25]. By locally heating and desorbing the ammonia stored on a SCR-catalyst while simultaneously monitoring its ionic conductivity, the quantity of stored ammonia can be estimated. The SCR catalyst material was deposited on an alumina substrate, which was equipped with electrodes for ac conductivity measurements and an embedded heater. During the loading mode, the device temperature was kept constant (different loading temperatures), ammonia was exposed to the sensor, and the material got ammonia-loaded. During the subsequent measurement mode, the temperature was increased to desorb or oxidize all ammonia stored during the previous loading phase [25]. Since the ac conductivity is correlated with the amount of stored ammonia and with temperature, an integral over the desorption current leads to the ammonia storage capacity [26]. Obviously, this type of sensor combined with the temperature alteration method can detect the loading degree of a zeolite SCR catalyst.

\section{Novel exhaust gas sensing methods}

In the previous section it has been shown that the electrical properties of the catalyst coating are a good indicator of the state of the catalyst. One can observe directly and in-situ the state of LNT and SCR catalysts. However, the presented methods require a coating that is applied on top of planar electrodes, which have to be contacted by wires. In order to avoid problems of mounting the planar substrates into the catalyst, a wireless method would be helpful. Recent attempts were conducted to gauge directly the state of catalysts directly by observing the penetration of the material by radio frequency waves [27], [28], [29], [30]. This method is possible for all catalysts with a coating that changes its electrical properties when storing gases like oxygen in the case of the TWC, NOx in the case of LNT, or $\mathrm{NH}_{3}$ in the case of SCR catalysts.

Since the stainless steel canning of the honeycomb is a good electrical conductor, from an electrical point of view, this system can be regarded as a circular cavity resonator. Two coaxial antennas (waveguide feeds) were mounted in the canning. Each of the waveguide feeds was connected to a coaxial line. The cavity resonator can be regarded as an electric twoport between two coaxial lines. Its frequency characteristics was determined by an automatic network analyzer. In essence, one lets electromagnetic waves of amplitudes $a_{1}$ and $a_{2}$ impinge onto ports one and two, respectively, and records the amplitudes $b_{1}$ and $b_{2}$ of the two backscattered waves. The wave amplitudes are related by

$$
\left(\begin{array}{l}
b_{1} \\
b_{2}
\end{array}\right)=\left(\begin{array}{ll}
s_{11} & s_{12} \\
s_{21} & s_{22}
\end{array}\right)\left(\begin{array}{l}
a_{1} \\
a_{2}
\end{array}\right)
$$


$S_{11}$ denotes the input reflection coefficient for matched output, $S_{22}$ denotes the output reflection coefficient for matched input, and the transfer function $S_{12}=S_{21}$ is a measure for the transmission of energy from one port to the other through the interior of the cavity resonator [28].

It was shown that the RF-signal of both $S_{21}$ and $S_{11}$ at the resonance frequencies shows a gradient as long as the catalyst is storing or releasing oxygen and it shows constant values as long as the catalyst is in a constant (oxidized or reduced) state. These results suggest that it is possible to infer from a RFsignal to the instantaneous oxidation state of the catalyst. In a preliminary explanation, it is assumed that the transmission increases with the oxygen stored in the catalyst coating since the ceria, which is responsible for the oxygen storage properties of the TWC coating, gets oxidized and its electrical conductivity decreases. Hence, the resonator S-parameters mirror the oxidation/reduction state of the TWC catalyst.

The RF technique provides an integral measurement of the device, so that a control of the catalyst is possible. Compared to $\lambda$-probes, this could be advantageous with regard to future on-board-diagnostics (OBD) for better monitoring exhaust aftertreatment components. The effect of changing transmission coefficients could be reproduced in synthetic exhausts as well as in engine test benches [27]. It is a reliable indication of the oxygen storage state of the TWC.

Initial test on LNT with the RF method were very promising. The signals are in accordance with the above-described contactless method [29].

\section{Conclusion}

For lean-burn engines (gasoline direct injection, Diesel), which become more and more popular, novel exhaust gas aftertreatment concepts are required. This pushed the development of novel types of sensors to be installed in the exhaust. NOx sensors, $\mathrm{NH}_{3}$ sensors, and sensors to directly detect the state catalysts are under development or in the research state. Additionally, contactless RF techniques were introduced to measure the catalyst state.

It should be emphasized that development of exhaust gas sensors has always to be considered in interaction with exhaust gas aftertreatment systems. Therefore, novel kinds of sensors have gained in importance just recently, when stricter emission regulations were announced, meaning that time is ripe for novel exhaust gas aftertreatment concepts.

However, it is clear that all novel sensors do not only have to meet the technical requirements of the automotive industry but also have to be very inexpensive, reliable, and cost-effective.

\section{References}

1. R. Moos, Automotive Exhaust Gas Sensors, In: C. A. Grimes, E. C. Dickey, M. V. Pishko (Eds.) Encyclopedia of Sensors, Vol. 1, p. 295 - 312, American Scientific Publishers (2006)

2. J. Schommers, C. Enderle, H. Breitbach, B. Lindemann, M. Stotz, M. Paule, World Wide Emission Strategy with BLUETEC for Diesel Passenger Cars, 15. Aachener Kolloquium Fahrzeug- und Motorentechnik 2006, 223-244 (2006)

3. N. Kato, K. Nakagaki, N. Ina, Thick Film $\mathrm{ZrO}_{2} \mathrm{NO}_{x}$ Sensor. SAE-Paper 960334 (1996)

4. T. Baunach, K. Schänzlin, L. Diehl, Sauberes Abgas durch Keramiksensoren, Physik Journal, 5, 3338 (2006)

5. H. Zhang, C. Pfleger, B. Lemire, Integration eines Smart NOx-Sensors im Abgasstrang für die Benzindirekteinspritzung. 21. Internationales Wiener Motorensymposium (4.-5. Mai 2000), in: Fortschrittberichte VDI Reihe 12, Nr. 420, Band 2, S. 288-311 (2000)

6. L. Hofmann, K. Rusch, S. Fischer, B. Lemire, Onboard emissions monitoring on a HD Truck with an SCR system using NOx sensors, SAE paper 2004-01-1290 (2004)

7. Y.W Kim, M. Van Nieuwstadt, Threshold Monitoring of Urea SCR Systems, SAE paper 2006-01-3548 (2006)

8. S. Zhuiykov, N. Miura, Development of zirconia-based potentiometric NOx sensors for automotive and energy industries in the early 21st century: What are the prospects for sensors?, Sensors and Actuators B: Chemical, 121, 639-651 (2007) 
9. J.W. Fergus, Materials for high temperature electrochemical NOx gas sensors, Sensors and Actuators B: Chemical, 121, 652-663 (2007)

10. C. Zimmermann, Neuartiger Sensor zur Bestimmung des Zustandes eines NOx-Speicherkatalysators, in: R. Moos u. G. Fischerauer (Hrsg.), Bayreuther Beiträge zur Sensorik und Messtechnik, Bd. 2, Shaker-Verlag, Aachen (2007)

11. R. Moos, C. Zimmermann, T. Birkhofer, A. Knezevic, C. Plog, M.R. Busch, T. Ried, Sensor for directly determining the state of a NOx storage catalyst, SAE paper 2008-01-0447 (2008)

12. T. Birkhofer, H. Leye, A. Knezevic, R. Moos, C. Plog, T. Ried, D. Voigtländer, Verfahren zur Zustandserkennung eines NOx-Speicherkatalysators, Offenlegungsschrift, DE 10064499

13. D.Y. Wang, S. Yao, D. Cabush, D. Racine, Ammonia Sensor for SCR NOX Reduction, 13th Diesel Engine-Efficiency and Emissions Research (DEER) Conference, Detroit, MI (2007)

14. D.Y. Wang, W. Symons, D. Cabush, V. Weisgerber, Ammoniaksensoren für die Regelung von SCRSystemen mit Harnstoffeinspritzung, in: T. Tille et al.: Sensoren im Automobil, expert Verlag, 49 - 58 (2006)

15. D.Y. Wang, W.T. Symons, R.J. Farhat, C.A. Valdes, E.M. Briggs, K.K. Polikarpus, J. Kupe, Ammonia gas sensor, US Patent Specification US 7,074,319 (2006)

16. D.Y Wang, S. Yao, M. Shost, J. Yoo, D. Cabush, D. Racine, R, Cloudt, F. Willems, Ammonia Sensor for Closed-Loop SCR Control, SAE paper 2008-01-0919 (2008)

17. D.Y. Wang, R.J. Farhat, Exhaust Gas Sensors and Methods for Measuring Concentrations of NOx and Ammonia and Temperatures of the Sensors, Offenlegungsschrift US 20080110769 (2008)

18. D. Schönauer, R. Moos, K. Wiesner, M. Fleischer, Selektiver Ammoniakabgassensor auf Mischpotentialbasis, in: G. Gerlach, P. Hauptmann (Hrsg.), 8. Dresdner Sensor-Symposium, 10.-12. Dezember 2007, Dresden, p. 11 -14 (2007)

19. D. Schönauer, R. Moos, M. Fleischer, K. Wiesner, Selective Mixed Potential Ammonia Exhaust Gas Sensor, The 12th International Meeting on Chemical Sensors, IMCS 12, Columbus, Ohio, 13th-16th July 2008, SCEA 7 (2008)

20. D. Schönauer, R. Moos, K. Wiesner, M. Fleischer, Selektiver neuartiger Ammoniakabgassensor auf Mischpotentialbasis, Sensoren im Automobil, 17.3.-18.3.2009, München (2009)

21. D. Schönauer, R. Moos, K. Wiesner, M. Fleischer, Selective Mixed Potential Ammonia Exhaust Gas Sensor, Submitted to Sensors and Actuators B: Chemical (2009)

22. P. Elumalai, V.V. Plashnitsa, Y. Fujio, N. Miura, Stabilized Zirconia-Based Sensor Attached with $\mathrm{NiO} / \mathrm{Au}$ Sensing Electrode Aiming for Highly Selective Detection of Ammonia in Automobile Exhausts, Electrochem. Solid-State Lett., 11, J79-J81 (2008)

23. D. Schmitt, et al., Smart NOx-Sensor für direkteinspritzende Ottomotoren, 2. Fahrzeugtechnisches Kolloquium, Coburg, 2003.

24. C.M. Schär, C.H. Onder, H.P. Geering, M. Elsener, Control of a urea SCR catalytic converter system for a mobile heavy duty diesel engine, SAE paper, 2003-01-0776 (2003).

25. D.J. Kubinski, J.H. Visser, Sensor and method for determining the ammonia loading of a zeolite SCR catalyst, Sensors and Actuators B: Chemical, 130, 425-429 (2008)

26. R. Moos, D. Schönauer, Review: Recent Developments in the Field of Automotive Exhaust Gas Ammonia Sensing, Sensor Letters, 6, 821-825 (2008)

27. R. Moos, M. Spörl, G. Hagen, A. Gollwitzer, M. Wedemann, G. Fischerauer, TWC: lambda control and OBD without lambda probe - an initial approach, SAE paper 2008-01-0916 (2008)

28. G. Fischerauer, M. Spörl, A. Gollwitzer, M. Wedemann, R. Moos, Catalyst State Observation via the Perturbation of a Microwave Cavity Resonator, Frequenz, 62, 180-184 (2008)

29. R. Moos , M. Wedemann, M. Spörl, S. Reiß, G. Fischerauer, Direct Catalyst Monitoring by Electrical Means - an Overview on Promising Novel Principles, CAPOC8, Brussels, Belgium, April 15 - 17, 2009

30. S. Reiß, R. Moos, M. Wedemann, M. Spörl, A. Nerowski, G. Fischerauer, RF-probing of Automotive Catalysts, Sensor 2009, 14th International Conference on Sensors, Technologies, Electronics and Applications, Nürnberg, 26.-28.5.2009 